\title{
Title: Anti-PEG antibodies boosted in humans by SARS-CoV-2 lipid nanoparticle mRNA vaccine
}

Authors: Yi Ju ${ }^{1,2,3^{*}}$, Wen Shi Lee ${ }^{1,4}$, Hannah G Kelly ${ }^{1}$, Emily H Pilkington ${ }^{1,5}$, Kathleen M Wragg $^{1}$, Kanta Subbarao ${ }^{1}$, Thi H.O. Nguyen ${ }^{1}$, Louise C. Rowntree ${ }^{1}$, Lilith F Allen ${ }^{1}$, Katherine Bond $^{6}$, Deborah A Williamson ${ }^{1,6}$, Nghia P Truong ${ }^{1,5}$, Magdalena Plebanski ${ }^{2}$, Katherine Kedzierska ${ }^{1}$, Siddhartha Mahanty $^{7}$, Frank Caruso ${ }^{3}$, Adam K Wheatley ${ }^{1}$, Jennifer A Juno ${ }^{1}$, Stephen J Kent ${ }^{1,8^{*}}$

\section{Affiliations:}

${ }^{1}$ Department of Microbiology and Immunology, Peter Doherty Institute for Infection and Immunity, The University of Melbourne, Melbourne, VIC, Australia

${ }^{2}$ School of Health and Biomedical Sciences, RMIT University, Bundoora, VIC, Australia

${ }^{3}$ Department of Chemical Engineering, The University of Melbourne, Melbourne, VIC, Australia

${ }^{4}$ The Walter and Eliza Hall Institute of Medical Research, Melbourne, VIC, Australia

${ }^{5}$ Department of Drug Delivery, Disposition and Dynamics, Monash Institute of Pharmaceutical Sciences, Monash University, Melbourne, VIC, Australia

${ }^{6}$ Department of Microbiology, Royal Melbourne Hospital, Melbourne, VIC, Australia

${ }^{7}$ Department of Infectious Diseases, Peter Doherty Institute for Infection and Immunity, The University of Melbourne, Melbourne, VIC, Australia

${ }^{8}$ Melbourne Sexual Health Centre and Department of Infectious Diseases, Alfred Hospital and Central Clinical School, Monash University, Melbourne, VIC, Australia

*Corresponding authors. Email skent@unimelb.edu.au; y.ju@unimelb.edu.au 


\section{Abstract:}

Humans commonly have low level antibodies to poly(ethylene) glycol (PEG) due to environmental exposure. Lipid nanoparticle mRNA vaccines for SARS-CoV-2 contain small amounts of PEG but it is not known if PEG antibodies are enhanced by vaccination and if there

are any consequences. We studied plasma from 55 people receiving the Comirnaty (PfizerBioNTech) mRNA vaccine for PEG-specific antibodies. Anti-PEG IgG was commonly detected prior to vaccination and was boosted a mean of 1.78 -fold (range 0.68 to 16.6 ) by vaccination. Anti-PEG IgM increased 2.64-fold (0.76 to 12.84) following vaccination. PEG antibodies did not impact the neutralizing antibody response to vaccination. Pre-existing levels of anti-PEG IgM correlated with increased reactogenicity. A rise in PEG antibodies following vaccination was associated with an increase in the association of PEG-based nanoparticles to blood immune cells ex vivo. We conclude that low level PEG-specific antibodies can be modestly boosted by a lipid nanoparticle mRNA-vaccine and that PEG-specific antibodies are associated with higher reactogenicity. The longer-term clinical impact of the increase in PEG-specific antibodies induced by lipid nanoparticle mRNA-vaccines should be monitored.

\section{One-Sentence Summary:}

A rise in PEG antibodies following mRNA lipid nanoparticle vaccination was associated with higher reactogenicity and PEG particle-leukocyte interactions. 
medRxiv preprint doi: https://doi.org/10.1101/2022.01.08.22268953; this version posted January 10, 2022. The copyright holder for this preprint (which was not certified by peer review) is the author/funder, who has granted medRxiv a license to display the preprint in perpetuity.

It is made available under a CC-BY-NC-ND 4.0 International license .

\section{Main Text:}

Humans are exposed to poly(ethylene) glycol (PEG) through consumer products and medicines. A proportion of adults have circulating anti-PEG antibodies.(1-5) Incorporation of PEG into the formulation of some systemically administered drugs to improve pharmacokinetics can result in anti-PEG antibodies that ultimately limit the bioavailability of the drug and can cause side effects.(6-8) Lipid nanoparticle mRNA vaccines for SARS-CoV-2 contain small amounts of a PEG-lipid conjugate to stabilise the lipid nanoparticle. $(9,10)$ An estimated $1.95 \mu \mathrm{g}$ and $6.01 \mu \mathrm{g}$ of the PEG-lipid conjugates ALC-0159 and PEG2000-DMG are present per dose for the BNT162b2 (Comirnaty, Pfizer-BioNTech) and mRNA-1273 (Spikevax, Moderna) vaccines, respectively.(11) Lipid nanoparticle SARS-CoV-2 mRNA vaccines containing PEG-lipids have now been given to 100's of millions of people worldwide. However, it is not known whether anti-PEG antibodies are induced or boosted by intramuscular lipid nanoparticle mRNA vaccination for COVID-19 and what effect, if any, this may have on vaccine responses.

We studied serial blood samples from 55 adults across 3 separate cohorts receiving 2 doses of the Comirnaty (Pfizer-BioNTech) COVID-19 vaccine (subject details in Supplementary Fig. 1). PEG-specific IgG and IgM antibodies were quantified by ELISA first to a 40 kilodalton PEG molecule as described in the Methods. PEG-specific IgG was detectable (endpoint titre >1:10) prior to vaccination in 40 of the 55 subjects (73\%), ranging in titre from 1:12-1:3000.

Of the 55 subjects, 26 subjects $(47 \%)$ had a titre $>1: 80$. In the literature, there is a wide range of prevalence of anti-PEG antibodies reported, ranging from $<4 \%$ to $72 \%,(3-5)$ potentially attributed to differences in geographic location, age of the blood donors as well as different assay systems used in the individual studies. A small but consistent increase in PEG-specific IgG was 
medRxiv preprint doi: https://doi.org/10.1101/2022.01.08.22268953; this version posted January 10, 2022. The copyright holder for this preprint (which was not certified by peer review) is the author/funder, who has granted medRxiv a license to display the preprint in perpetuity. It is made available under a CC-BY-NC-ND 4.0 International license .

observed after 2 vaccinations with a mean fold change of 1.78 , range $0.68-16.6$, across all 55 subjects. A rise in PEG-specific IgG was observed in 37 subjects (67\%), mainly in those with pre-existing antibodies (35 subjects) (Fig. 1A, Supplementary Fig. 2A). PEG-specific IgM antibodies also increased after vaccination with a mean fold change of 2.64, range 0.76-12.84, across all 55 subjects. Forty-one of the 55 subjects had a rise in PEG-specific IgM following vaccination, including 11 who did not develop PEG-specific IgG responses. There were 9 (16\%) and $23(42 \%)$ of subjects who had a boost of anti-PEG IgG and IgM with more than 2-fold change after vaccination, respectively. A time course analysis showed that subjects with increased PEG antibody responses had a stepwise increase after the first and second vaccination (Supplementary Fig. 3). PEG antibodies did not increase further out to 3 months in a subset of subjects $(\mathrm{n}=10)$ where late post-vaccination samples were available (Supplementary Fig. 3B). As a control group, we studied plasma samples from 55 unvaccinated subjects across 2 separate cohorts (40 SARS-CoV-2 infected convalescent subjects and 15 healthy donors) over a 6-month period (subject details in Supplementary Fig. 4). In contrast to the Comirnaty vaccinated group, anti-PEG IgG and IgM titres did not increase and overall slightly decreased over a 6-month period with a mean fold change of 0.92 and 0.98 , respectively, across the 55 unvaccinated control subjects (Figure 1B, Supplementary Fig. 2B).

The anti-PEG IgG response following Comirnaty vaccination was gender- and age-dependent. Females had higher titres of pre-existing anti-PEG IgG than males (mean titre 1:74 vs. 1:35, Fig. $1 \mathrm{C}$, left). This is consistent with previous findings and has been postulated to be related to greater exposure of females to PEG-containing cosmetic products.(3) Females had a higher rise of anti-PEG IgG after Comirnaty vaccination than males (mean fold change 2.12 vs. 1.19, Fig. 
medRxiv preprint doi: https://doi.org/10.1101/2022.01.08.22268953; this version posted January 10, 2022. The copyright holder for this preprint (which was not certified by peer review) is the author/funder, who has granted medRxiv a license to display the preprint in perpetuity. It is made available under a CC-BY-NC-ND 4.0 International license .

$1 \mathrm{C}$, right). We found the age of donors was negatively correlated with the pre-existing levels and change in anti-PEG IgG after vaccination (Fig. 1D). Younger subjects have been previously reported to have higher PEG-specific antibodies in a large serosurvey.(3) Younger age was also associated with a greater boost to anti-PEG IgG following Comirnaty vaccination than older subjects. We did not observe an influence of gender or age on the change in anti-PEG IgM after vaccination although pre-existing anti-PEG IgM showed a negative correlation with age (Supplementary Fig. 5)

To determine whether the PEG antibodies detected specifically recognised the PEG-lipid or other synthetic lipid components of the Comirnaty vaccine, we assessed a subset of 18 vaccinees where larger plasma samples were available for antibody response to the ALC-0159 (PEG-lipid), ALC-0315 (ionizable lipid), and DSPC (helper lipid) components of the Comirnaty vaccine. We found anti-human IgG that was specific to the ALC-0159 PEG-lipid increased in 10 out of 18 subjects studied (mean fold change 3.03, range 1-27.4, Fig. 2A). The boost of PEG-lipidspecific IgG correlated with the increase of PEG-specific IgG from the same subjects detected using a 40 kilodalton PEG (Fig.2B). In contrast, the other lipid components, ALC-0315 and DSPC, elicited no antibody responses before or after vaccination (Fig. 2C). Furthermore, a humanized monoclonal anti-PEG IgG was used to assess specificity to the synthetic lipid components of Comirnaty vaccine. We found the monoclonal anti-PEG IgG specifically recognised the ALC-0159 (PEG-lipid) and 40 kilodalton PEG in a concentration-dependent manner, whilst it did not recognise ALC-0315 or DSPC (Fig. 2D). Taken together, these results suggest antibody recognition of PEG in the PEG-lipid component of the Comirnaty vaccine occurs in vaccinees. 
medRxiv preprint doi: https://doi.org/10.1101/2022.01.08.22268953; this version posted January 10, 2022. The copyright holder for this preprint (which was not certified by peer review) is the author/funder, who has granted medRxiv a license to display the preprint in perpetuity.

It is made available under a CC-BY-NC-ND 4.0 International license .

PEG is a hydrophilic compound commonly formulated with therapeutics to reduce non-specific immune clearance. Anti-PEG antibodies can reduce the bioavailability and efficacy of PEGcontaining therapeutics.(6) To determine the potential of anti-PEG antibodies induced by Comirnaty vaccination to promote immune-mediated clearance of nanomaterials containing PEG, we used a previously developed ex vivo human blood immune cell-particle association assay (Experimental design shown in Fig. 3A).(12) We first analysed the association of a fluorescently labelled PEG-based nanomaterial, a 100 nm PEGylated mesoporous silica particle termed PEG-MS (characterisation in Supplementary Fig. 6). The assay incubates nanoparticles for $1 \mathrm{hr}$ with fresh primary human blood cells containing monocytes, granulocytes, and B cells in the presence of plasma before and after Comirnaty vaccination and measures nanoparticle and immune cell association by flow cytometry (details in Methods, gating strategy shown in Supplementary Fig. 7). The PEG-MS nanoparticles displayed a range of plasma donor-dependent association with immune cells, consistent with our previous findings.(13) Baseline levels of PEG IgG (rather than IgM) antibodies correlated with the association of PEG-MS nanoparticles with primary human immune cells ex vivo, illustrating that PEG-specific antibodies influence the behaviour of PEGylated nanoparticles (Fig. 3B, Supplementary Fig. 8A). The biggest dynamic range of association was with B cells, likely mediated by antibody-mediated attachment to B cell complement receptors since heat inactivation of plasma has previously been shown to inhibit this association.(14) We found that there was an increase in the association of PEG-MS particles with B cells when plasma was obtained after vaccination (Fig. 3D, left). The degree of increase in anti-PEG IgM antibodies after vaccination correlated with the increase in association of PEG-MS particles to B cells (Fig. 3D, right). In contrast, changes in monocyte or granulocyte association 
medRxiv preprint doi: https://doi.org/10.1101/2022.01.08.22268953; this version posted January 10, 2022. The copyright holder for this preprint (which was not certified by peer review) is the author/funder, who has granted medRxiv a license to display the preprint in perpetuity.

It is made available under a CC-BY-NC-ND 4.0 International license .

with PEG-MS particles were minimal for most of plasma donors after vaccination and did not show a significant correlation with change in anti-PEG antibodies (Figure Supplementary Fig. 8B,C).

To further probe the potential clinical significance of anti-PEG antibodies enhanced by lipid nanoparticle vaccination, we studied blood immune cell association of PEGylated doxorubicinencapsulated liposomes that contain the same lipid composition and drug/lipid ratio as clinically used liposomal doxorubicin agent for anti-cancer chemotherapy called Doxil (characterisation in Supplementary Fig. 6). We found the pre-existing levels of anti-PEG IgG correlated with the association of Doxil with monocytes and granulocytes (Fig. 3C), while pre-existing levels of anti-PEG IgM correlated with Doxil association with B cell (Supplementary Fig. 9A). We observed an increase in monocyte association with Doxil mediated by plasma after vaccination, which correlated with the level of changes in anti-PEG IgM levels in plasma (Fig. 3E). The change in B cell association of Doxil also correlated with the change in anti-PEG IgM levels (Supplementary Fig. 9B). The change in granulocyte association of Doxil correlated with the change in the levels of anti-PEG IgG and anti-PEG IgM in plasma after vaccination (Supplementary Fig. 9C). These ex vivo results across two independent particle systems show anti-PEG antibodies in the blood impact immune cell interactions with PEG-based nanomaterials. Further, the increased level of anti-PEG antibodies induced by lipid nanoparticle vaccination enhanced human immune cell association of the PEG-containing therapeutic Doxil. Plasma proteins are known to opsonize foreign nanomaterials in the blood, forming so-called "protein corona",(15-17) which leads to recognition and inactivation of nanomaterials by immune system.(18-21) In our previous studies, we found that the enrichment of 
medRxiv preprint doi: https://doi.org/10.1101/2022.01.08.22268953; this version posted January 10, 2022. The copyright holder for this preprint (which was not certified by peer review) is the author/funder, who has granted medRxiv a license to display the preprint in perpetuity.

It is made available under a CC-BY-NC-ND 4.0 International license .

immunoglobulins in protein coronas is correlated with donor-specific nanoparticle association with human blood immune cells.(13) The studies herein demonstrate that anti-PEG antibodies are key immunoglobulins that drive the person-specific immune cell association of PEGcontaining nanoparticles in human blood.

Many PEG-based therapeutics are delivered intravenously to promote biodistribution throughout the body and anti-PEG antibodies can interfere with this process. Intramuscular vaccination, however, exerts its effect primarily via the vaccine traversing lymphatics and stimulating immunity in the draining lymph node. This process may be less impacted by systemic anti-PEG antibodies. The impact of PEG-specific antibodies on vaccination was analyzed by quantifying SARS-CoV-2-specific neutralizing antibody levels 2 to 7 weeks after the second vaccination using a live virus neutralisation assay, since neutralization responses have emerged as a key correlate of protective immunity.(22) All 55 vaccinated subjects generated neutralizing antibody responses to SARS-CoV-2 after the second vaccine (median 346, range 103-1848 ID $_{50}$ ). There was no correlation between the absolute levels or change of PEG-specific IgG or IgM antibodies before or after vaccination and the neutralizing antibody titres (Figure 4A, Supplementary Fig. 10). This suggests PEG antibodies induced by 2 doses of Comirnaty do not interfere with vaccine immunogenicity.

There has been speculation that anti-PEG antibody responses may be involved in reactogenicity and anaphylaxis associated with COVID-19 lipid mRNA nanoparticle vaccination.(23-27) We assessed self-reported local and systemic reactions to the Comirnaty vaccination from a subset of 44 of the 55 vaccinees where reactogenicity data was available (Supplementary Fig. 1,12,13) and 
medRxiv preprint doi: https://doi.org/10.1101/2022.01.08.22268953; this version posted January 10, 2022. The copyright holder for this preprint (which was not certified by peer review) is the author/funder, who has granted medRxiv a license to display the preprint in perpetuity.

It is made available under a CC-BY-NC-ND 4.0 International license .

its association with anti-PEG antibodies. Reactogenicity was scored as the sum of local and systemic adverse events. Vaccine reactions were generally mild and no subjects experienced anaphylaxis or myocarditis in our small cohort. As previously reported, reactogenicity was higher after the second Comirnaty vaccination.(28) We found no association between vaccine reactogenicity and the pre-existing levels of anti-PEG IgG or the increased levels of anti-PEG antibodies (Supplementary Fig. 11). However, we found that the pre-existing anti-PEG IgM levels correlated with a higher rate of reactogenicity after both the first and second vaccinations (Fig. 4B). Larger studies are required to confirm these data and to determine if changes in reactogenicity are associated with the modest induction or boosting of anti-PEG antibodies following future regimens utilizing further doses.

We conclude that low level PEG-specific IgG and IgM antibody responses are modestly but significantly boosted by the PEG-lipid contained in the Comirnaty SARS-CoV-2 lipid nanoparticle vaccine. PEG-specific antibodies present prior to or following vaccination did not negatively impact the immune response to 2 doses of the vaccine. However, even the small boost of anti-PEG antibodies detected following vaccination was found to impact the association of PEGylated nanomedicines with monocytes, granulocytes and B cells ex vivo. This suggests it will be important to assess the impact of lipid nanoparticle vaccination on the biology of other PEGylated medicines. Importantly, higher pre-existing anti-PEG IgM levels were found to correlate with higher reactogenicity of the vaccine. Larger and longer studies are needed to analyze the longer-term impact of boosting anti-PEG antibodies by lipid nanoparticle mRNA vaccination. Booster doses of SARS-CoV-2 lipid nanoparticle mRNA vaccines, now commonly recommended to enhance immunity(29) and for emerging variants of SARS-CoV-2,(30) as well 
medRxiv preprint doi: https://doi.org/10.1101/2022.01.08.22268953; this version posted January 10, 2022. The copyright holder for this preprint (which was not certified by peer review) is the author/funder, who has granted medRxiv a license to display the preprint in perpetuity. It is made available under a CC-BY-NC-ND 4.0 International license.

as new mRNA lipid nanoparticle vaccines and therapies for other infectious diseases or cancers(31) may further increase PEG-specific antibodies. Generating next-generation lipid nanoparticles with alternatives to PEG(32) may be useful for overcoming PEG immunogenicity in the future. 
medRxiv preprint doi: https://doi.org/10.1101/2022.01.08.22268953; this version posted January 10, 2022. The copyright holder for this preprint (which was not certified by peer review) is the author/funder, who has granted medRxiv a license to display the preprint in perpetuity. It is made available under a CC-BY-NC-ND 4.0 International license .

\section{References}

1. H. Freire Haddad, J. A. Burke, E. A. Scott, G. A. Ameer, Clinical relevance of pre-existing and treatment-induced anti-poly(ethylene glycol) antibodies. Regen. Eng. Transl. Med. DOI: 10.1007/s40883-021-00198-y (2021).

2. R. P. Garay, R. El-Gewely, J. K. Armstrong, G. Garratty, P. Richette, Antibodies against polyethylene glycol in healthy subjects and in patients treated with PEG-conjugated agents. Expert Opin. Drug Delivery 9, 1319-1323 (2012).

3. B.-M. Chen, Y.-C. Su, C.-J. Chang, P.-A. Burnouf, K.-H. Chuang, C.-H. Chen, T.-L. Cheng, Y.-T. Chen, J.-Y. Wu, S. R. Roffler, Measurement of pre-existing IgG and IgM antibodies against polyethylene glycol in healthy individuals. Anal. Chem. 88, 10661-10666 (2016).

4. Q. Yang, T. M. Jacobs, J. D. McCallen, D. T. Moore, J. T. Huckaby, J. N. Edelstein, S. K. Lai, Analysis of pre-existing IgG and IgM antibodies against polyethylene glycol (PEG) in the general population. Anal. Chem. 88, 11804-11812 (2016).

5. C. Lubich, P. Allacher, M. de la Rosa, A. Bauer, T. Prenninger, F. M. Horling, J. Siekmann, J. Oldenburg, F. Scheiflinger, B. M. Reipert, The mystery of antibodies against polyethylene glycol (PEG) - what do we know? Pharm. Res. 33, 2239-2249 (2016).

6. G. T. Kozma, T. Shimizu, T. Ishida, J. Szebeni, Anti-PEG antibodies: Properties, formation, testing and role in adverse immune reactions to PEGylated nano-biopharmaceuticals. $A d v$. Drug Delivery Rev. 154-155, 163-175 (2020).

7. P. Zhang, F. Sun, S. Liu, S. Jiang, Anti-PEG antibodies in the clinic: Current issues and beyond pegylation. J. Controlled Release 244, 184-193 (2016).

8. Q. Yang, S. K. Lai, Anti-PEG immunity: Emergence, characteristics, and unaddressed questions. WIREs Nanomed. and Nanobiotechnol. 7, 655-677 (2015).

9. E. H. Pilkington, E. J. A. Suys, N. L. Trevaskis, A. K. Wheatley, D. Zukancic, A. Algarni, H. Al-Wassiti, T. P. Davis, C. W. Pouton, S. J. Kent, N. P. Truong, From influenza to covid-19: Lipid nanoparticle mRNA vaccines at the frontiers of infectious diseases. Acta Biomater. 131, 16-40 (2021). 
medRxiv preprint doi: https://doi.org/10.1101/2022.01.08.22268953; this version posted January 10, 2022. The copyright holder for this preprint (which was not certified by peer review) is the author/funder, who has granted medRxiv a license to display the preprint in perpetuity. It is made available under a CC-BY-NC-ND 4.0 International license .

10. R. Verbeke, I. Lentacker, S. C. De Smedt, H. Dewitte, The dawn of mRNA vaccines: The covid-19 case. J. Controlled Release 333, 511-520 (2021).

11. L. Schoenmaker, D. Witzigmann, J. A. Kulkarni, R. Verbeke, G. Kersten, W. Jiskoot, D. J. A. Crommelin, Mrna-lipid nanoparticle covid-19 vaccines: Structure and stability. Int. J. Pharm. 601, 120586 (2021).

12. J. Song, Y. Ju, T. H. Amarasena, Z. Lin, S. Mettu, J. Zhou, M. A. Rahim, C.-S. Ang, C. Cortez-Jugo, S. J. Kent, F. Caruso, Influence of poly(ethylene glycol) molecular architecture on particle assembly and ex vivo particle-immune cell interactions in human blood. ACS Nano 15, 10025-10038 (2021).

13. Y. Ju, H. G. Kelly, L. F. Dagley, A. Reynaldi, T. E. Schlub, S. K. Spall, C. A. Bell, J. Cui, A. J. Mitchell, Z. Lin, A. K. Wheatley, K. J. Thurecht, M. P. Davenport, A. I. Webb, F. Caruso, S. J. Kent, Person-specific biomolecular coronas modulate nanoparticle interactions with immune cells in human blood. ACS Nano 14, 15723-15737 (2020).

14. A. C. G. Weiss, H. G. Kelly, M. Faria, Q. A. Besford, A. K. Wheatley, C.-S. Ang, E. J. Crampin, F. Caruso, S. J. Kent, Link between low-fouling and stealth: A whole blood biomolecular corona and cellular association analysis on nanoengineered particles. ACS Nano 13, 4980-4991 (2019).

15. M. P. Monopoli, C. Aberg, A. Salvati, K. A. Dawson, Biomolecular coronas provide the biological identity of nanosized materials. Nat. Nanotechnol. 7, 779-786 (2012).

16. M. Hadjidemetriou, S. McAdam, G. Garner, C. Thackeray, D. Knight, D. Smith, Z. AlAhmady, M. Mazza, J. Rogan, A. Clamp, K. Kostarelos, The human in vivo biomolecule corona onto pegylated liposomes: A proof-of-concept clinical study. Adv. Mater. 31, 1803335 (2019).

17. C. Corbo, R. Molinaro, M. Tabatabaei, O. C. Farokhzad, M. Mahmoudi, Personalized protein corona on nanoparticles and its clinical implications. Biomater. Sci. 5, 378-387 (2017).

18. D. Docter, D. Westmeier, M. Markiewicz, S. Stolte, S. K. Knauer, R. H. Stauber, The nanoparticle biomolecule corona: Lessons learned - challenge accepted? Chem. Soc. Rev. 44, 6094-6121 (2015). 
19. C. D. Walkey, W. C. Chan, Understanding and controlling the interaction of nanomaterials with proteins in a physiological environment. Chem. Soc. Rev. 41, 2780-2799 (2012).

20. G. Caracciolo, O. C. Farokhzad, M. Mahmoudi, Biological identity of nanoparticles in vivo: Clinical implications of the protein corona. Trends Biotechnol. 35, 257-264 (2017).

21. F. Giulimondi, L. Digiacomo, D. Pozzi, S. Palchetti, E. Vulpis, A. L. Capriotti, R. Z. Chiozzi, A. Laganà, H. Amenitsch, L. Masuelli, M. Mahmoudi, I. Screpanti, A. Zingoni, G. Caracciolo, Interplay of protein corona and immune cells controls blood residency of liposomes. Nat. Commun. 10, 3686 (2019).

22. D. S. Khoury, D. Cromer, A. Reynaldi, T. E. Schlub, A. K. Wheatley, J. A. Juno, K. Subbarao, S. J. Kent, J. A. Triccas, M. P. Davenport, Neutralizing antibody levels are highly predictive of immune protection from symptomatic sars-cov-2 infection. Nat. Med. 27, 1205$1211(2021)$.

23. J. de Vrieze, Suspicions grow that nanoparticles in pfizer's covid-19 vaccine trigger rare allergic reactions. Science Published Online Available at https://doi.org/10.1126/science.abg2359

24. K. A. Risma, K. M. Edwards, D. S. Hummell, F. F. Little, A. E. Norton, A. Stallings, R. A. Wood, J. D. Milner, Potential mechanisms of anaphylaxis to covid-19 mRNA vaccines. $J$. Allergy Clin. Immunol. 147, 2075-2082.e2072 (2021).

25. J. Kleine-Tebbe, L. Klimek, E. Hamelmann, O. Pfaar, C. Taube, M. Wagenmann, T. Werfel, M. Worm, Severe allergic reactions to the covid-19 vaccine - statement and practical consequences. Allergol Select 5, 26-28 (2021).

26. V. Erdeljic Turk, Anaphylaxis associated with the mrna covid-19 vaccines: Approach to allergy investigation. Clin. Immunol. 227, 108748 (2021).

27. P. Bigini, M. Gobbi, M. Bonati, A. Clavenna, M. Zucchetti, S. Garattini, G. Pasut, The role and impact of polyethylene glycol on anaphylactic reactions to covid-19 nano-vaccines. Nat. Nanotechnol. 16, 1169-1171 (2021).

28. F. P. Polack, S. J. Thomas, N. Kitchin, J. Absalon, A. Gurtman, S. Lockhart, J. L. Perez, G. Perez Marc, E. D. Moreira, C. Zerbini, R. Bailey, K. A. Swanson, S. Roychoudhury, K. 
medRxiv preprint doi: https://doi.org/10.1101/2022.01.08.22268953; this version posted January 10, 2022. The copyright holder for this preprint (which was not certified by peer review) is the author/funder, who has granted medRxiv a license to display the preprint in perpetuity. It is made available under a CC-BY-NC-ND 4.0 International license .

Koury, P. Li, W. V. Kalina, D. Cooper, R. W. Frenck, Jr., L. L. Hammitt, O. Tureci, H. Nell, A. Schaefer, S. Unal, D. B. Tresnan, S. Mather, P. R. Dormitzer, U. Sahin, K. U. Jansen, W. C. Gruber, C. C. T. Group, Safety and efficacy of the BNT162b2 mRNA covid-19 vaccine. $N$ Engl J Med 383, 2603-2615 (2020).

29. Y. M. Bar-On, Y. Goldberg, M. Mandel, O. Bodenheimer, L. Freedman, N. Kalkstein, B. Mizrahi, S. Alroy-Preis, N. Ash, R. Milo, Protection of BNT162b2 vaccine booster against covid-19 in israel. New Engl. J. Med. 385, 1393-1400 (2021).

30. K. Wu, A. Choi, M. Koch, L. Ma, A. Hill, N. Nunna, W. Huang, J. Oestreicher, T. Colpitts, H. Bennett, H. Legault, Y. Paila, B. Nestorova, B. Ding, R. Pajon, J. M. Miller, B. Leav, A. Carfi, R. McPhee, D. K. Edwards, Preliminary analysis of safety and immunogenicity of a sars-cov-2 variant vaccine booster. medRxiv Preprint at https://doi.org/10.1101/2021.05.05.21256716 (2021).

31. C. Chakraborty, A. R. Sharma, M. Bhattacharya, S.-S. Lee, From covid-19 to cancer mrna vaccines: Moving from bench to clinic in the vaccine landscape. Front. Immunol. 12, 2648 (2021).

32. T. T. Hoang Thi, E. H. Pilkington, D. H. Nguyen, J. S. Lee, K. D. Park, N. P. Truong, The importance of poly(ethylene glycol) alternatives for overcoming peg immunogenicity in drug delivery and bioconjugation. Polymers 12, 298 (2020). 
medRxiv preprint doi: https://doi.org/10.1101/2022.01.08.22268953; this version posted January 10, 2022. The copyright holder for this preprint (which was not certified by peer review) is the author/funder, who has granted medRxiv a license to display the preprint in perpetuity.

It is made available under a CC-BY-NC-ND 4.0 International license .

\section{Acknowledgments}

We thank all the dedicated participants involved in the studies. We thank Thakshila Amarasena, Helen Kent, Jeni Mitchell, Chioma Uzoho, Barbara Scher, Dilini Rathnayake, Honghua Ding and Louise Randall for expert assistance.

\section{Funding}

Australian Medical Research Future Fund grants 2005544

Australian Research Council awards DP210103114 and DP200100231

Australian National Health and Medical Research Council grants 1149990

Australian National Health and Medical Research Council Investigator or Fellowship grants

(SJK, KK, JJ, AKW, FC, DAW and THON)

RMIT Vice Chancellor's Postdoctoral Fellowship (YJ)

Author contributions: YJ and SK conceived, designed, and supervised the study and drafted the manuscript. YJ, WSL, HK, EP and JJ performed experiments and provided technical advice. KS, TN, LR, LA, KB, DW, KW, AW, JJ, and SK recruited subjects and processed their blood samples. MP, NT and FC provided intellectual input and reagents. All authors approved the final version of the manuscript.

Competing interests: Authors declare that they have no competing interests.

Data and materials availability: All data are available in the main text or the supplementary materials. 
medRxiv preprint doi: https://doi.org/10.1101/2022.01.08.22268953; this version posted January 10, 2022. The copyright holder for this preprint (which was not certified by peer review) is the author/funder, who has granted medRxiv a license to display the preprint in perpetuity.

It is made available under a CC-BY-NC-ND 4.0 International license .

\section{Supplementary Materials}

Materials and Methods

Supplementary Fig. 1 | Comirnaty Vaccinee information

Supplementary Fig. 2 The impact of Comirnaty vaccination on the levels of PEG specific antibodies.

Supplementary Fig. 3 |Time course of PEG antibodies following Comirnaty vaccination.

Supplementary Fig 4 | Unvaccinated control blood donor information

Supplementary Fig. 5 | Impact of Sex and Age on Anti-PEG IgM response.

Supplementary Fig 6 | Size and zeta potential of PEG-MS and Doxil nanoparticles

Supplementary Fig. 7 | Gating strategy used to identify white blood cell populations.

Supplementary Fig. 8 | The impact of PEG specific antibody on PEGylated nanoparticle (PEGMS) association with human blood immune cells.

Supplementary Fig. 9 | The impact of PEG specific antibody on PEGylated nanomedicine (Doxil) association with human blood immune cells.

Supplementary Fig. 10 | The impact of PEG specific antibody on neutralizing antibody responses.

Supplementary Fig. 11 | The impact of PEG specific antibody on reactogenicity.

Supplementary Fig. 12 | Reported reactogenicity after prime of Comirnaty vaccination

Supplementary Fig. 13 | Reported reactogenicity after boost of Comirnaty vaccination 


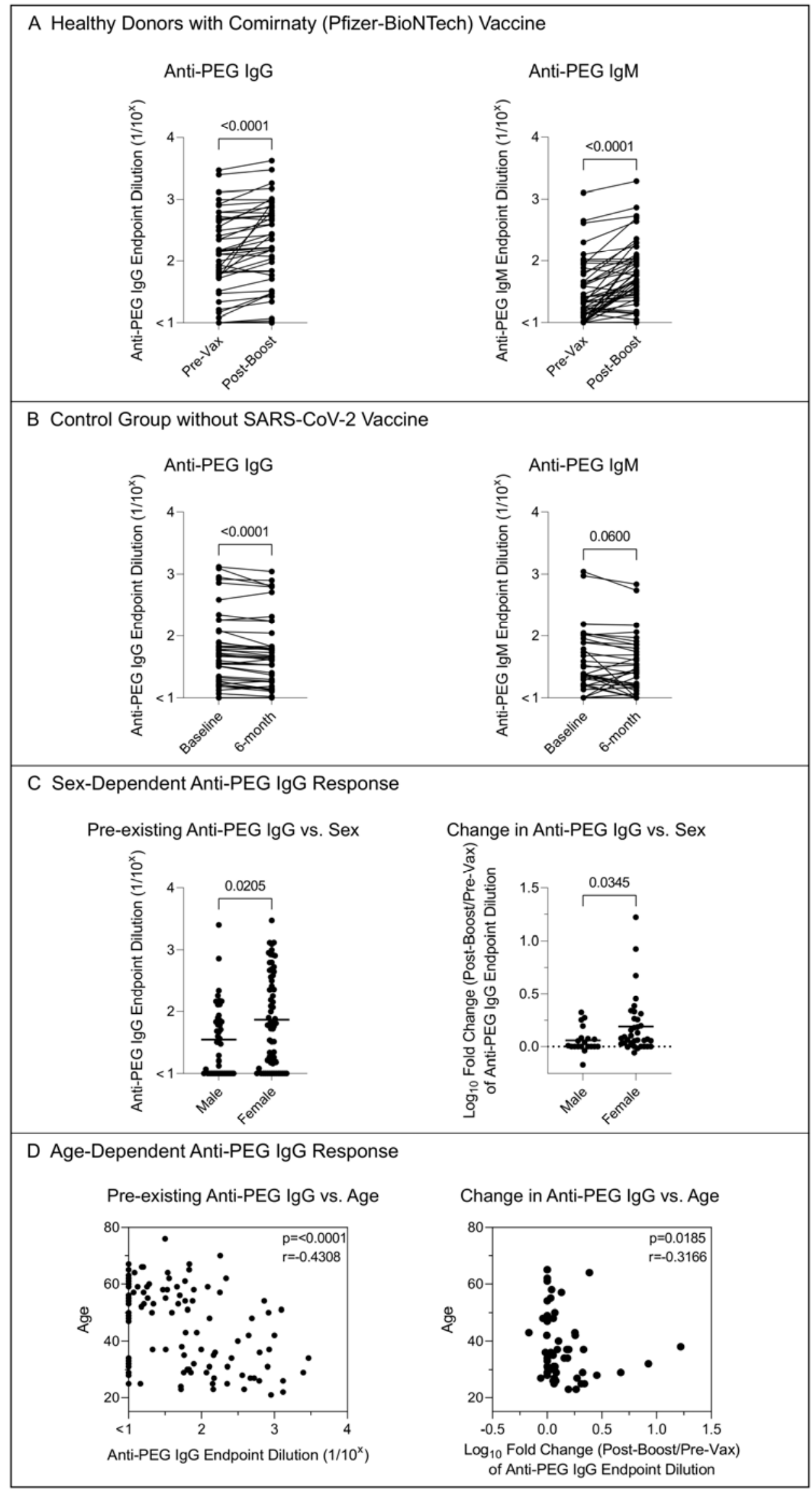


medRxiv preprint doi: https://doi.org/10.1101/2022.01.08.22268953; this version posted January 10, 2022. The copyright holder for this preprint (which was not certified by peer review) is the author/funder, who has granted medRxiv a license to display the preprint in perpetuity.

It is made available under a CC-BY-NC-ND 4.0 International license .

Fig. 1 | The impact of Comirnaty vaccination on the levels of PEG specific antibodies.

A) Comparing plasma anti-PEG IgG and IgM titres before and 2 to 7 weeks (mean 27 days, range $12-49)$ following the Comirnaty vaccination of healthy cohort $(n=55)$. $p$-values were derived by Wilcoxon's matched-pairs signed rank test.

B) Comparing plasma anti-PEG IgG and IgM titres over a 6-month period (mean 186 days, range 120-253) of unvaccinated control cohort ( $\mathrm{n}=55$, including 40 SARS-CoV-2 infected convalescent patients and 15 healthy donors). p-values were derived by Wilcoxon's matchedpairs signed rank test.

C) Sex-dependent anti-PEG IgG response. Left: comparing the pre-existing (baseline) anti-PEG IgG titres between male and female donors (including all the vaccinated and unvaccinated control cohorts, $n=110)$. Right: Sex effect on the fold change $\left(\log _{10}\right)$ in anti-PEG IgG titres at 2 to 7 weeks post-boost compared to baseline ( $n=55$ from Comirnaty vaccinated cohorts). $p$-values were derived by Mann-Whitney $U$ test.

D) Age-dependent anti-PEG response. Left: Spearman correlation between age of donors and the pre-existing anti-PEG IgG titres (including all the vaccinated and unvaccinated control cohorts, $\mathrm{n}=110)$. Right: Spearman correlation between age of donors and the fold change $\left(\log _{10}\right)$ of antiPEG IgG titre at 2 to 7 weeks post-boost compared to baseline ( $\mathrm{n}=55$ from Comirnaty vaccinated cohorts). 


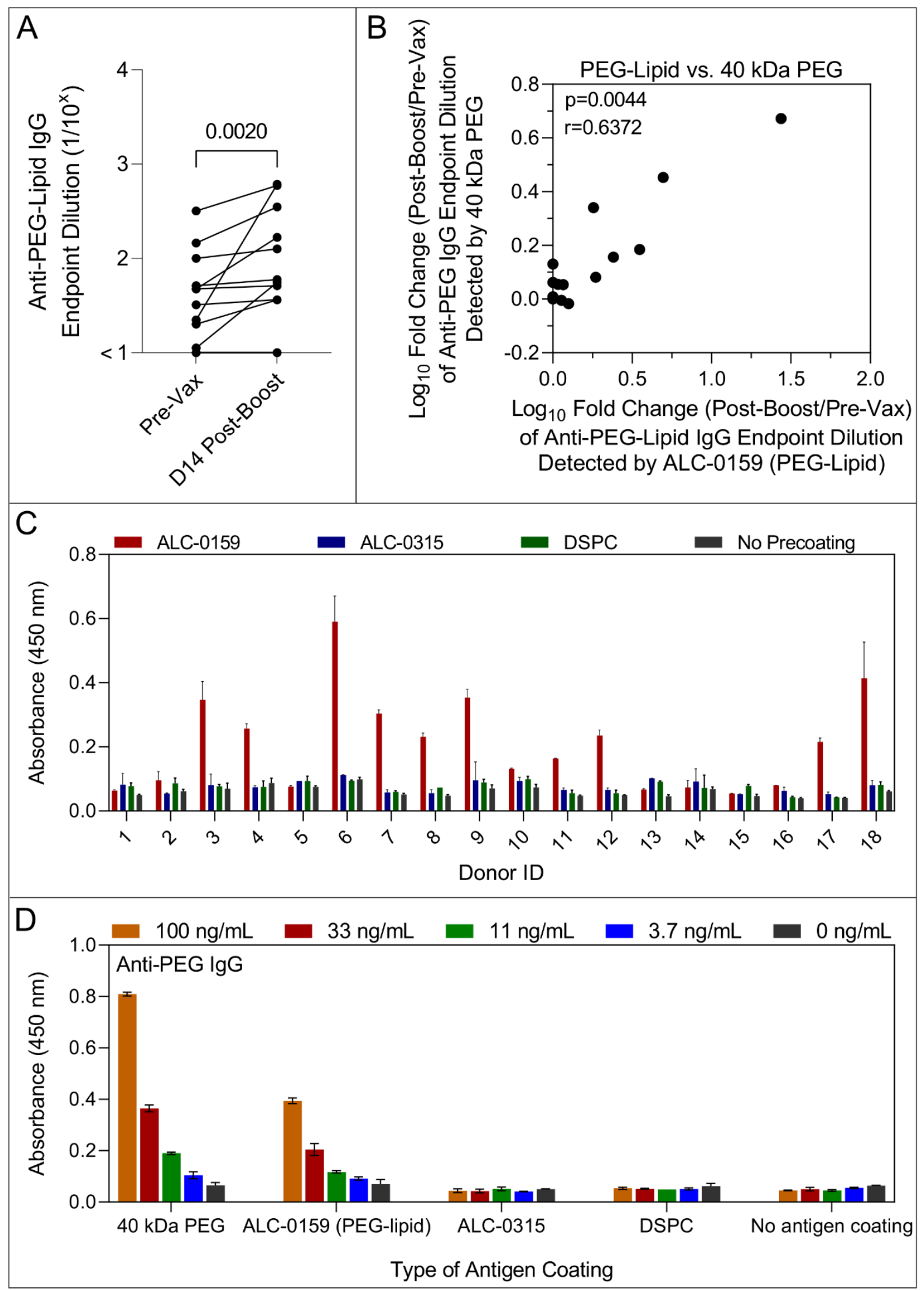


Fig. 2 | Specificity of PEG specific antibodies to PEG-lipid and other synthetic lipid

\section{components of Comirnaty vaccine}

A) PEG-lipid-specific IgG titres before and day 14 following 2 doses of the Comirnaty vaccination in 18 healthy subjects across cohort 1 . The ELISA were performed by coating ALC-

0159 (PEG-lipid contained in the Comirnaty vaccine) on hydrophobic plates. p-values were derived by Wilcoxon's matched-pairs signed rank test.

B) Spearman correlation between the fold change $\left(\log _{10}\right)$ of anti-PEG-lipid IgG titres detected by ALC-0159 and the fold change of anti-PEG IgG titres detected by 40 kilodalton PEG at day 14 post-boost compared to baseline ( $\mathrm{n}=18$ from cohort 1$)$.

C) ELISA assay of anti-human IgG specific to lipid nanoparticle components ALC-0159 (PEGlipid), ALC-0315 (ionizable lipid), and DSPC (helper lipid) in comparison to background (no antigen precoating) of 18 healthy subjects across cohort 1 at day 14 following Comirnaty vaccination (two doses). The ELISA were performed by coating individual lipid components (ALC-0159, ALC-0315, and DSPC) on hydrophobic plates and the plasma were diluted at 1:10 in $5 \%$ skim milk. Data are shown as mean $\pm \mathrm{SD}$ (duplicate samples).

D) Specificity of monoclonal anti-PEG IgG to 40 kilodalton (kDa) PEG, ALC-0159, ALC-0315, and DSPC, which were pre-coated as antigen on hydrophobic ELISA plates. Data are shown as mean \pm SD (duplicate samples). 


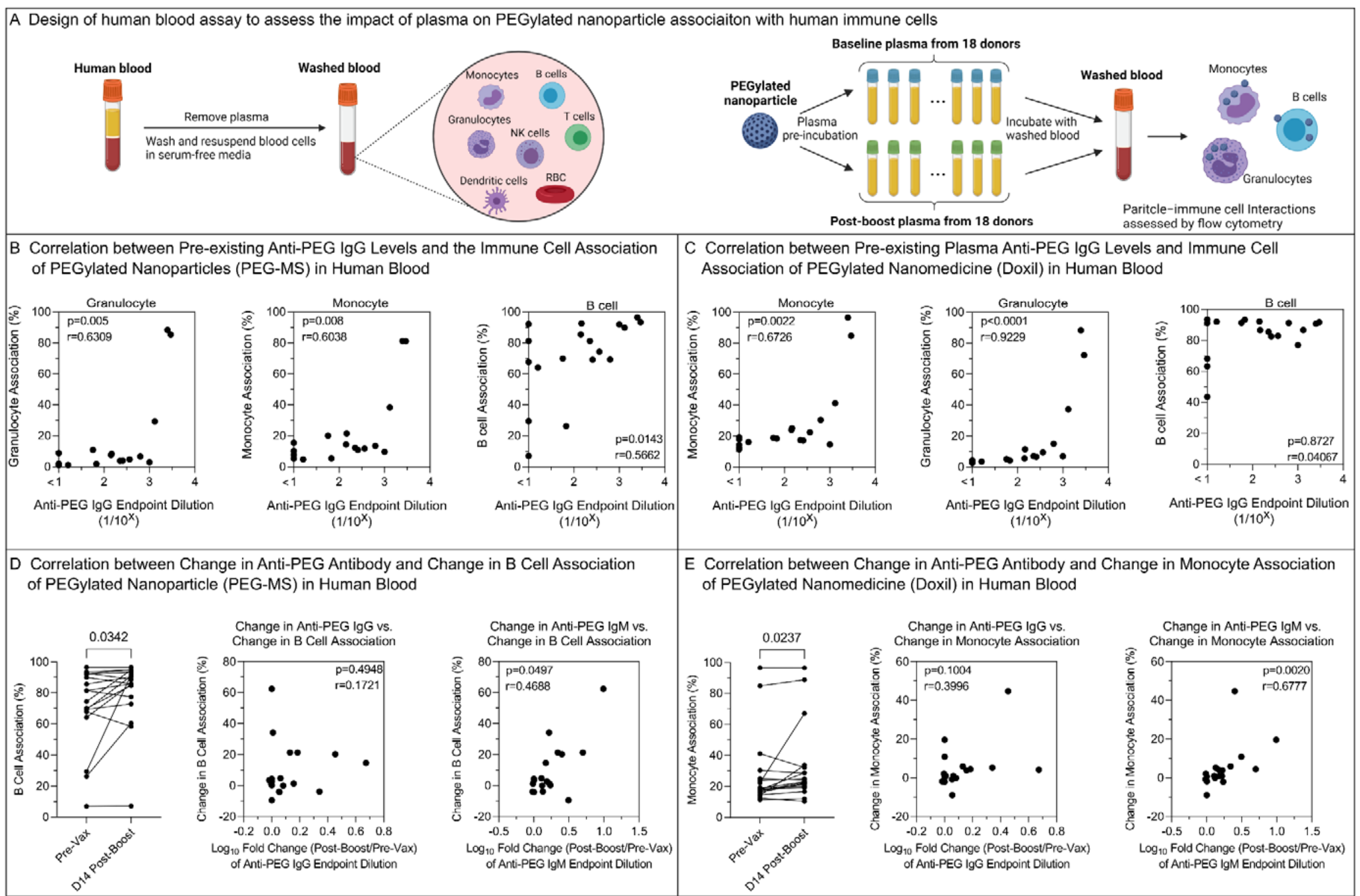




\section{Fig. 3 | The impact of PEG specific antibody in plasma on human blood immune cell association of PEGylated nanoparticles.}

A) Design of human blood assay to assess the impact of plasma on PEGylated nanoparticle association with human immune cells. Fresh human blood from a healthy donor was washed by centrifugation with serum-free media mutliple times to completely remove plasma. PEGylated nanoparticles were pre-incubated with plasma from 18 donors accoss Cohort 1 before and day 14 post-boost of Comirnaty vaccination, and then incubated with washed blood in serum-free media for $1 \mathrm{~h}$ at $37^{\circ} \mathrm{C}$, followed by phenotyping cells with antibody cocktails and analysis by flow cytometry. Created with BioRender.com.

B,C) Spearman correlation between pre-existing (pre-vaccination) anti-PEG IgG titres ( $\mathrm{n}=18$ from Cohort 1) and PEG-MS or Doxil nanoparticle association with monocytes, granulocytes, and B cells in human blood.

D) Left: Comparing B cell association with PEG-MS nanoparticles before (Pre-Vax) and day 14 post boost of the Comirnaty vaccination of 18 subjects across Cohort 1. p-values were derived by Wilcoxon's matched-pairs signed rank test. Middle \& Right: spearman correlation between the change in B cell association of PEG-MS nanoparticle and the fold change $\left(\log _{10}\right)$ in plasma anti-PEG IgG or antiPEG IgM titres at 2 weeks post-boost compared to baseline ( $\mathrm{n}=18$ from Cohort 1$)$.

E) Left: Comparing monocyte association with Doxil before (Pre-Vax) and day 14 post boost of the Comirnaty vaccination of 18 subjects across Cohort 1. p-values were derived by Wilcoxon's matched-pairs signed rank test. Middle \& Right: spearman correlation between the change in monocyte association of Doxil and the fold change $\left(\log _{10}\right)$ in plasma anti-PEG IgG or anti-PEG IgM titres at 2 weeks postboost compared to baseline ( $\mathrm{n}=18$ from Cohort 1$)$. 
A Correlation between Change in Anti-PEG Antibody and Neutralizing Antibody Responses
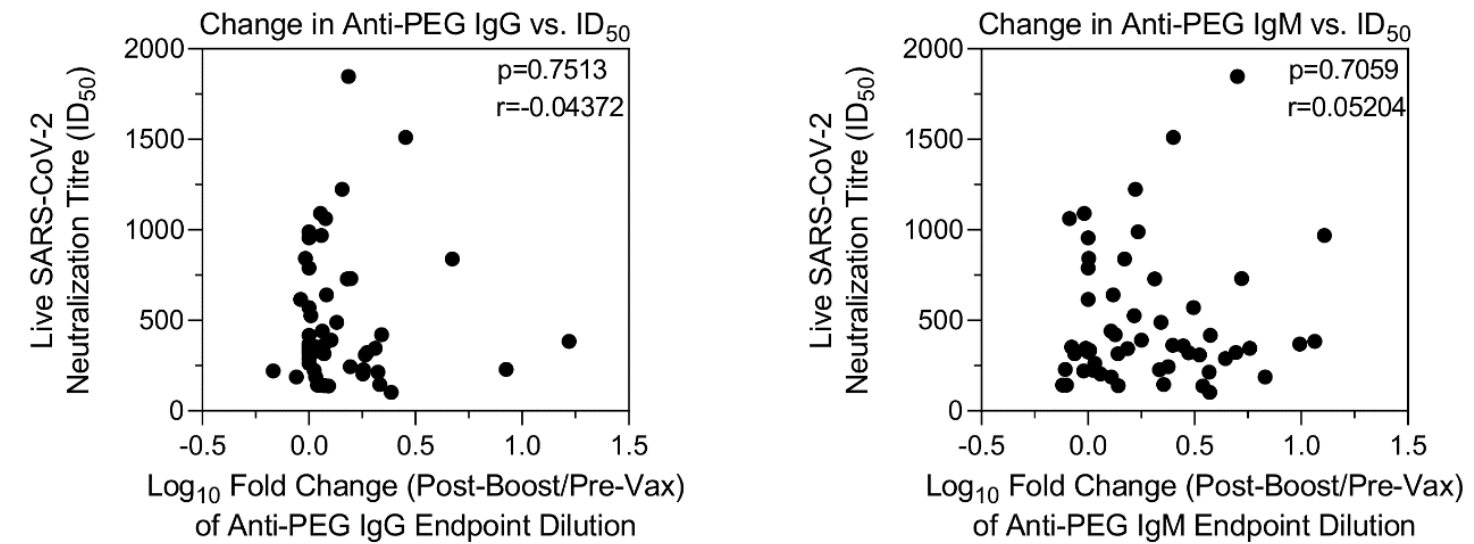

B Correlation between Pre-existing Anti-PEG IgM Levels and Reactogenicity
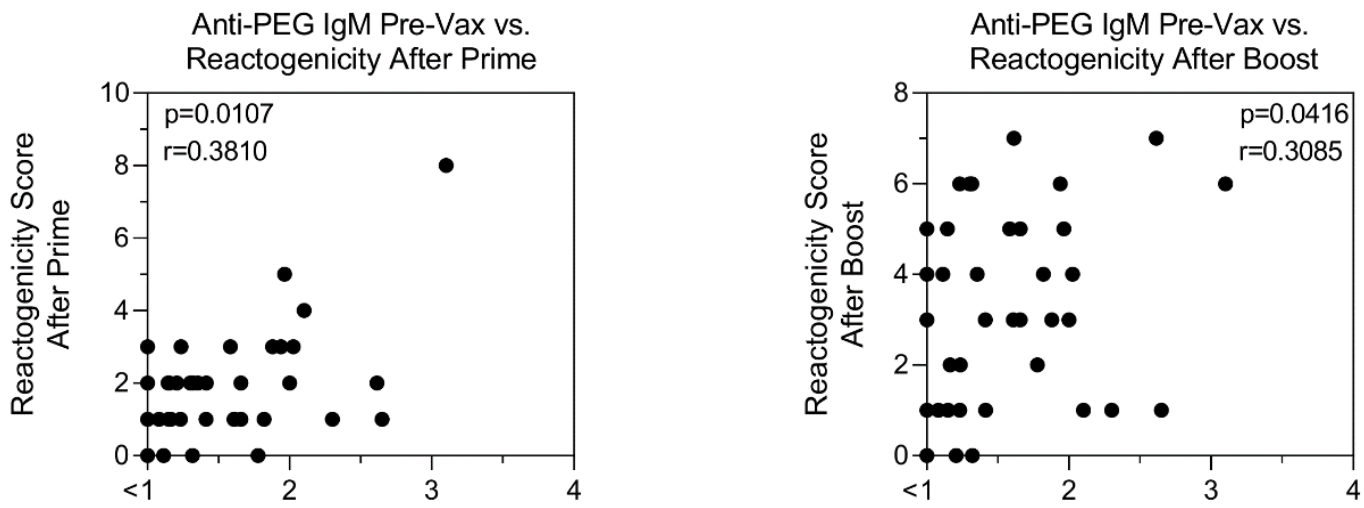

Anti-PEG IgM Endpoint Dilution $\left(1 / 10^{\mathrm{x}}\right)$

Anti-PEG IgM Endpoint Dilution $\left(1 / 10^{\mathrm{x}}\right)$

Fig. 4 | The impact of PEG specific antibody on neutralizing antibody responses and reactogenicity after Comirnaty vaccination.

A) Spearman correlation between live SARS-COV-2 neutralization titre (inhibitory dilution 50,

$\left.\mathrm{ID}_{50}\right)$ and the fold change $\left(\log _{10}\right)$ of anti-PEG IgG or anti-PEG IgM titre at 2 to 7 weeks post-

boost compared to baseline $(\mathrm{n}=55)$.

B) Spearman correlation between pre-existing anti-PEG IgM titres and reactogenicity scores post-prime or post-boost $(\mathrm{n}=44)$. 